\title{
Pineapple Production Status in Bangladesh
}

\author{
Md. Farid Hossain ${ }^{1}$, Md. Anwarul Islam² \\ ${ }^{1}$ School of Agriculture and Rural Development, Bangladesh Open University, Gazipur, Bangladesh \\ ${ }^{2}$ School of Education, Bangladesh Open University, Gazipur, Bangladesh \\ Email address: \\ faridhossain04@yahoo.com (Md. F. Hossain), anwarul2003islam@yahoo.com (Md. A. Islam)
}

\section{To cite this article:}

Md. Farid Hossain, Md. Anwarul Islam. Pineapple Production Status in Bangladesh. Agriculture, Forestry and Fisheries. Vol. 6, No. 5, 2017, pp. 173-177. doi: 10.11648/j.aff.20170605.15

Received: July 11, 2015; Accepted: July 30, 2015; Published: October 2, 2017

\begin{abstract}
This review paper discussed the area, production, yield and importance of pineapple in Bangladesh. Production of pineapple shows an upward trend in Bangladesh. Total 39583 acres (16025 ha) of land was cultivated with the production of 234493 m tones pineapple in 2009-2010. The highest cultivated area, production and yield was observed in Dhaka division. It is widely cultivated in Tangail, Mymensingh, Gazipur, Sylhet, Moulvibazar, Chittagong, Bandarban, Khagrachari and Rangamati districts. Tangail district of Dhaka Division is the pioneer of pineapple production. It covered $49 \%$ of total pineapple cultivated land and 59\% of national production. Generally, the ripen pineapple fruit is consumed freshly and used as source of various food items like jam, jelly, pickles in Bangladesh. Recently, pineapple growers and sellers are using some health hazard chemical such as hormone or and preservative to get attractive pineapple round the year. The demand of pineapple for internal consumption and also for export is increasing day by day. Every year a large amount of pineapple damage results due to lack of appropriate storage, transportation and marketing facilities. So, expansion of pineapple cultivation through proper management can improve the socioeconomic conditions of farmers in Bangladesh.
\end{abstract}

Keywords: Pineapple, Importance, Area, Yield, Bangladesh

\section{Introduction}

Pineapple is a delicious tropical fruit with a fine flavor and high nutritive value. It is one of the most important commercial fruit crops in the world. Thailand is the largest producer of pineapple, accounting for $13 \%$ of global output, followed by Brazil and Costa Rica [1]. Pineapple is a common fruit in Bangladesh and it contains good amount of various vitamins, carbohydrates, crude fiber, water and different minerals that is good for the digestive system and helps in maintaining ideal weight and balanced nutrition. Pineapple has minimal fat, sodium and contains vitamins [2, 3]. The fruit is widely taken for fresh consumption as well as juice. Among all the fruits produced in the country, pineapple ranks 4th in terms of total area and production [4]. Each year a huge amount of pineapples of different varieties is produced in Bangladesh. This fruit is highly perishable and seasonal. If the excess fruits in the season were preserved by any means ensuring the quality, consumers would have the opportunity to taste this seasonal fruit all around the year round and also these processed fruits could be exported to earn foreign currency [5]. Generally, it is grown almost all over Bangladesh especially in hilly and high land area. It is widely cultivated in the districts of Tangail, Mymensingh, Gazipur, Sylhet, Moulvibazar, Chittagong, Bnandarban, Khagrachari and Rangamati. Pineapple is extensively cultivated in all over Madhupur Upazila of Tangail District [6]. June, July and August are the peak time of pineapple harvesting in Bangladesh. Only a few pineapples are harvested during September and October. Generally, the ripen pineapple is consumed by the people of Bangladesh. Green pineapple is also used for making pickles. After extraction of its juice, the left over is used as livestock feed and also the tender leaves are used for the same purpose. Various food items like squash, syrup, jelly, etc. are produced from pineapple. Vinegar, alcohol, citric acid, calcium citrate etc are also produced from pineapple. Pineapple is also recommended as medical diet for certain diseased persons [7]. Mature fruit contains $14 \%$ of sugar; a protein digesting enzyme, bromelin and good amount of citric acid, melic acid and vitamin A and B. At least ninety varieties of pineapple are cultivated in the world. In Bangladesh, however, three varieties of pineapple are mostly grown. The three varieties 
are: Giant Kew, Honey Queen and Ghorasal. In the Tangail area, mainly Giant Kew variety of pineapple has intensively been cultivated by the farmers for the last few years. One local variety named "Asshina" is grown by a few farmers of Tangail district [8]. The variety Honey Queen is largely produced in Chittagong hilly zone. Seasonal Bangladeshi fruits are being exported to different countries of the world. Pineapple fruits are primarily used in fresh fruit; canning and juice concentrate with characteristic requirements of size, shape, colour, aroma and flavor [9]. Pineapple grows in warm and humid climate. The optimum temperature is from $15^{\circ}$ to $32^{\circ} \mathrm{C}$ for normal growth. High temperature over $35^{\circ} \mathrm{C}$ is unfavorable for the development of fruits, especially if the relative humidity is low. Exposure of the fruits to strong sunshine leads to sun scalding. It can be grown up to an elevation of $1,100 \mathrm{~m}$ above the sea level, if these places are free from frost, have a relatively high atmospheric humidity and an average rainfall of 760-1,000 $\mathrm{mm}$ [10]. Soil most suitable for pineapple are well drained loam or sandy loam and laterite soils of the hills, which are generally rich in organic matter . Fruit size is larger on a heavy soil, but flavor of the fruit is better when grown on a lighter soil. It needs an acidic soil with $\mathrm{pH}$ ranging from 4.5-5.5 and rich in iron and calcium. On the hills it can be grown successfully, provided the soil depth is at least 45 to $60 \mathrm{~cm}$ [11]. The pineapple plants are drought tolerant and well adapted to the tropical sandy soils with $\mathrm{pH}$ ranging from 4.5 to 6.5 [12]. Pineapple is propagated asexually from various plant parts. The parts are crowns, slips and suckers. Crowns and slips are most common. Recently in Bangladesh, people are consuming fruits, ripened with hazardous chemicals like calcium carbide. This poses great health risks to consumers [13]. Consumers prefer large, bright pineapples but naturally grown fruit is not so large or brightly colored as its chemically-treated competitor Farmers growing pineapples without chemical and hormone additives are facing mounting losses because demand for their product is proving to be weak. Madhupur pineapples of Tangail district lost their original flavor because of the unrestricted use of growth hormones and chemicals. Many farmers spray growth boosting chemicals and hormones on pineapple flowers to produce large fruit and then apply hormones to immature fruit to early harvesting [14]. The use of artificial agents may give more acceptable color than naturally ripened fruits [15] but it may increase the risk of contamination of food materials. The use of toxic ripening agents is common in developing countries. Artificial ripening accelerates ripening, but affects the nutritional quality of the fruits [16]. The demand of pineapple fruits is increasing abroad day by day. Fruit preservation, processing and marketing are the major problems in Bangladesh. The prospect of pineapple farming is bright in this country. These pineapples are sure to fetch huge amounts of foreign currency through exports. In spite of its position among the fruit crops of Bangladesh, limited studies have been done regarding area, production, yield, nutritional value and problems of pineapple under different zones of Bangladesh. Thus, the present study provided an assessment of area, production, yield, problems and impact of pineapple production in Bangladesh.

\section{Methodology}

In this study, the divisional and districts data of cultivated area, yield and production of pineapple were collected from Bangladesh Bureau of Statistics [17]. Interviews with pineapple farmers, wholesalers and retailers were conducted purposively during January 2013 to July 2014 in Tangail, Mymensingh, Gazipur, Sylhet, Chittagong and Dhaka district. The information out lined of this article have been collected from different national and international organizations, journals, reports and visiting of useful internet, website etc.

\section{Results and Discussions}

\subsection{Area, Production and Yield of Pineapple}

Production data of pineapple has been showing an upward trend in Bangladesh. Total 38989 acres and 39583 acres of land were under pineapple cultivation with a total production of $229069 \mathrm{~m}$ tones and $234493 \mathrm{~m}$ tones in the year of 20082009 and 2009-2010, respectively (Table 1). In 2009-2010, Pineapples cultivated 26392 acres in Dhaka division (Table 1) of which 19761 acre are in Tangail district (Table 2). About 9466 acres of land was under pineapple farming in Chittagong division which includes Rangamati, Bandarban and Khagrachori hilly districts. Pineapples was cultivated in 9466 acres in Sylhet Division including Habiganj, Moulvibazar districts (Table 1).

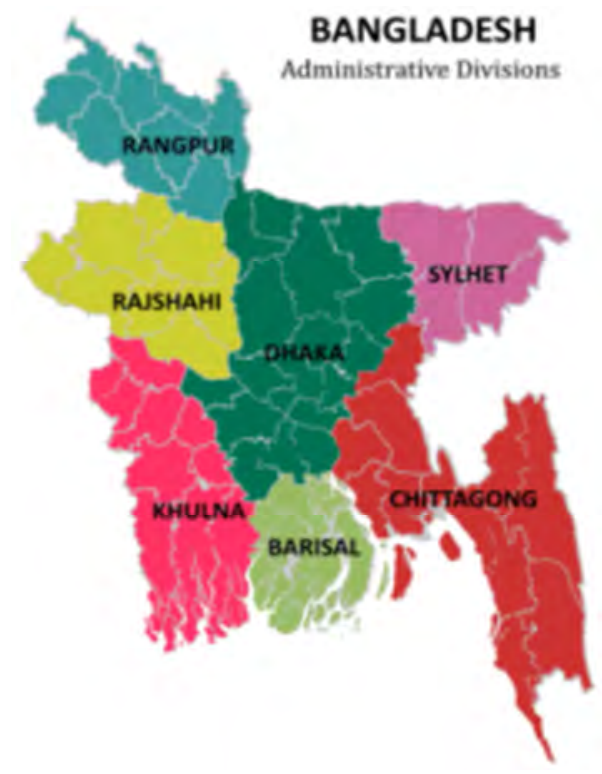

Figure 1. Seven Divisions of Bangladesh.

Pineapple is widely cultivated in the districts of Tangail, Mymensingh, Gazipur, Sylhet, Moulvibazar, Chittagong, Bandarban, Khagrachari and Rangamati. The highest yield was observed in Dhaka Division and the lowest yield was 
observed in Barisal Division in both the year. The lowest cultivated area and production of Rajshahi Division was
199,198 acres and 547, $571 \mathrm{~m}$ tones in 2008-2009 and 20092010, respectively (Table 1).

Table 1. Division wise area, yield and production of Pineapple in Bangladesh (2008-2009 and 2009-2010) [17].

\begin{tabular}{|c|c|c|c|c|c|c|c|}
\hline \multirow{3}{*}{ Division } & \multirow{3}{*}{$\begin{array}{l}\text { Total Area } \\
\text { ('000'acres) }\end{array}$} & \multicolumn{2}{|l|}{ Area (acre) } & \multicolumn{2}{|c|}{ Yield (M. ton/acre) } & \multicolumn{2}{|c|}{ Production (M. Ton) } \\
\hline & & \multicolumn{2}{|c|}{1 hectare $=2.47$ acres } & \multicolumn{2}{|c|}{1000 kg= 1 M.ton } & \multicolumn{2}{|c|}{1000 kg= 1 M.ton } \\
\hline & & 2008-2009 & $2009-2010$ & 2008-2009 & 2009-2010 & 2008-2009 & 2009-2010 \\
\hline Dhaka & 7705 & 26171 & 26392 & 6.56 & 6.58 & 171628 & 173766 \\
\hline Khulna & 5546 & 383 & 385 & 2.84 & 2.92 & 1089 & 1127 \\
\hline Sylhet & 3113 & 1942 & 1946 & 3.42 & 3.53 & 6643 & 6863 \\
\hline Rajshahi & 4494 & 199 & 198 & 2.75 & 2.88 & 547 & 571 \\
\hline Chittagong & 8505 & 9109 & 9466 & 5.14 & 5.25 & 46791 & 49685 \\
\hline Barisal & 3285 & 480 & 478 & 1.52 & 1.59 & 728 & 762 \\
\hline Total & 36669 & 38989 & 39583 & 5.87 & 5.92 & 229069 & 234493 \\
\hline
\end{tabular}

The highest yield (7041 kg/ acre) was observed in Tangail district of Dhaka division in 2009-2010 but the highest yield (7050 kg/acre) in Rangamati district of Chittagong division in 2008-2009. The lowest yield (1157 kg/ acre) was found in Barguna district of Barisal division among the 20 top listed pineapple growing district of Bangladesh in 2009-2010 (Table 2).

Table 2. Area, yield and production of Pineapple in major 20 districts of Bangladesh (2008-2009 and 2009-2010) [17].

\begin{tabular}{|c|c|c|c|c|c|c|}
\hline \multirow{3}{*}{ Districts } & \multicolumn{2}{|c|}{ Area (Acre) } & \multicolumn{2}{|c|}{ Yield (Kg/Acre) } & \multicolumn{2}{|c|}{ Production (M.Ton) } \\
\hline & 2008-09 & 2009-10 & 2008-09 & 2009-10 & 2008-09 & 2009-10 \\
\hline & \multicolumn{4}{|c|}{1 hectare $=2.47$ acres } & \multicolumn{2}{|c|}{1000 kg= 1 M.ton } \\
\hline Tangail & 19187 & 19761 & 7040 & 7041 & 135078 & 139133 \\
\hline Gazipur & 3510 & 3435 & 5125 & 5128 & 17989 & 17615 \\
\hline Rangamati & 3133 & 3157 & 7050 & 7035 & 22087 & 22209 \\
\hline Mymensingh & 2679 & 2422 & 5700 & 5675 & 15271 & 13745 \\
\hline Chittagong & 2189 & 2377 & 4542 & 4464 & 9964 & 10611 \\
\hline Bandarban & 1436 & 1493 & 3976 & 4738 & 5710 & 7074 \\
\hline Habiganj & 738 & 740 & 2145 & 2299 & 1583 & 1701 \\
\hline Maulavi Bazar & 686 & 686 & 3536 & 3671 & 2426 & 2518 \\
\hline Sylhet & 455 & 456 & 5110 & 5110 & 2325 & 2330 \\
\hline Narsingdhi & 445 & 434 & 4762 & 4931 & 2119 & 2140 \\
\hline Cox's Bazar & 319 & 317 & 6464 & 6628 & 2062 & 2101 \\
\hline Panchagar & 265 & 275 & 2845 & 2833 & 754 & 779 \\
\hline Barguna & 138 & 134 & 1232 & 1157 & 170 & 155 \\
\hline Rangpur & 136 & 127 & 2184 & 2299 & 297 & 292 \\
\hline Jamalpur & 133 & 143 & 2947 & 2839 & 392 & 406 \\
\hline Kishreganj & 111 & 110 & 4027 & 3973 & 447 & 437 \\
\hline Noagaon & 108 & 114 & 3315 & 3342 & 358 & 381 \\
\hline Bangladesh & 38989 & 39583 & 5875 & 5924 & 229069 & 234493 \\
\hline
\end{tabular}

Table 3. Area (\%) and production (\%) of Pineapple in major districts of Bangladesh (2008-09 and 2009-10) [17].

\begin{tabular}{|c|c|c|c|c|c|}
\hline \multirow[t]{2}{*}{ Rank } & \multirow[t]{2}{*}{ Districts } & \multicolumn{2}{|c|}{$\begin{array}{l}\text { Area } \\
\text { (\% of total pineapple cultivated area) }\end{array}$} & \multicolumn{2}{|c|}{$\begin{array}{l}\text { Production (\%) } \\
\text { (\% of total pineapple production) }\end{array}$} \\
\hline & & 2008-09 & 2009-10 & 2008-09 & 2009-10 \\
\hline 1. & Tangail & 49.21 & 49.92 & 58.99 & 59.33 \\
\hline 2 & Gazipur & 9.00 & 8.68 & 7.85 & 7.51 \\
\hline 3. & Rangamati & 8.01 & 7.98 & 9.64 & 9.47 \\
\hline 4. & Mymensingh & 6.87 & 6.11 & 6.67 & 5.86 \\
\hline 5. & Chittagong & 5.61 & 6.00 & 4.35 & 4.52 \\
\hline 6. & Khagrachhari & 4.11 & 4.28 & 2.49 & 2.72 \\
\hline 7. & Bandarban & 3.68 & 3.77 & 2.49 & 3.02 \\
\hline 8. & Habiganj & 1.89 & 1.87 & 0.69 & 0.72 \\
\hline 9. & Maulavi Bazar & 1.76 & 1.73 & 1.06 & 1.07 \\
\hline 10. & Sylhet & 1.17 & 1.15 & 1.01 & 0.99 \\
\hline
\end{tabular}

Tangail district of Dhaka division is the pioneer of pineapple production considering area, yield and production. About $49 \%$ of total cultivated area and $59 \%$ of total pineapple production was covered by Tangail district in
2008-2009 and 2009- 2010 year respectively (Table 3). The climatic condition and soil properties of Tangail and Rangamati district are more favorable for pineapple cultivation. Most probably, this is the cause of higher yield, 
production and quality of pineapple. On the other hand, yield was lowest in southern districts of Barisal division due to climate, topography, soil fertility and salinity which are the major limiting factor for suitability of pineapple.

\subsection{Major Problems of Pineapple Consumer and Farmers in Bangladesh}

1. To attract the consumers, farmers/whole sellers use unauthorized hormone to get bigger size pineapple round the year.

2. Growers used carbide for ripening pineapple without recommended dose and formalin for preservation.

3. Damage of a large amount of pineapple every year due to lack of storage and transportation facilities.

4. The growers compelled to sell the pineapple at a low price in peak season due to lack of proper marketing facilities.

5. Prevalent constraints to pineapple production are shortage of high quality planting materials.

6. Lack of access to credit facilities.

\subsection{Recommendations}

1. Banned the using and marketing of health hazard unauthorized chemicals such as hormone, pesticide, preservative etc.

2. Seized the unauthorized chemicals, sprayer and imposed fines on guilty people through mobile courts.

3. Government, concerned health authorities and law enforcing agencies should pay more attention to control illegal use of hormones, herbicide, pesticide etc.

4. Raise a massive awareness generating campaign against the use of toxic chemicals in fruits.

5. Develop new variety and technology to produce hues amount of quality pineapple.

6. Make sufficient number of processing centre, cold storage in different growing zones.

7. Developed pineapple marketing and export facilities through government and NGO have to gear up the rural socio-economic condition and earn foreign currency.

\section{Conclusion}

The climate and the soils of Bangladesh are suitable for pineapple production. It is widely cultivated in the districts of Tangail, Mymensingh, Gazipur, Sylhet, Moulvibazar, Chittagong, Bandarban, Khagrachari and Rangamati. The three varieties namely Giant Kew, Honey Queen and Ghorasal are cultivated in Bangladesh. The highest cultivated area, production and yield was observed in Dhaka division. Tangail district of Dhaka division covered about $49 \%$ of total pineapple cultivated area and $59 \%$ of total production. Pineapple contains good amount of vitamins and minerals with medicinal value. Every year large amount of pineapple damaged for lack of storage and transportation facilities. The growers compelled to sell the pineapple at a low price in peak season due to lack of proper marketing facilities.
Government agencies should pay more attention to control illegal used health hazard chemical in pineapple. It has an export potentiality to earn foreign currency. Pineapple cultivation plays a vital role to improving socio-economic conditions of the growing areas of Bangladesh.

\section{Acknowledgement}

The authors are grateful to Bangladesh Bureau of Statistics (BBS) for providing the necessary data that used in this study and extend thanks to Dr. Md. Touhidul Islam, School of Agriculture and Rural Development, Bangladesh Open University for his valuable suggestions and cordial cooperation.

\section{References}

[1] Baruwa, O. I. 2013. Profitability and constraints of pineapple production in Osun State, Negeria. 2013. Journal of Horticultural Research. 21(2):59-64. [DOI: 10.2478/johr2013-0022].

[2] Sabahelkhier, K. M., Hussain, A. S. and Ishag, K. E. A. 2010. Effect of maturity stage on protein fractionation, in vitro protein digestibility and anti-nutrition factors in pineapple (Ananas comosus) fruit grown in Southern Sudan. Afr. J. Food Sc.4 (8):550-552.

[3] Rasid, Kader and Hosain. 1987. Fruits of Bangladesh, 1st ed.232pp. Rashid Publishing House, Joydevpur, Gazipur, Bangladesh

[4] BBS, 2009. Statistical Pocket Book Bangladesh, Yearbook of Bangladesh Bureau of Statistics (BBS). Peoples Republic of Bangladesh, Dhaka, 208 p.

[5] Bala, B. K., Mondol, M. R. A., Biswas, B. K. and Chowdury, B. L. D. 2001. Solar Drying of Pineapple Using Solar Tunnel Drier. 4th International Conference on Mechanical Engineering, December 26-28, 2001, Dhaka, Bangladesh/pp. I47-51.

[6] Hasan, S. S., Ali, M. A. and Khalil. M. I. 2010. Impact of Pineapple Cultivation on the Increased Income of Pineapple Growers. The Agriculturists 8(2): 50-56.

[7] Moniruzzaman, F. M. 1988. Bangladesh Faler Chash (Fruit Cultivation in Bangladesh), 2nd Edition, Bangla Academy, Dhaka.

[8] Mondol, M. F and Mrittunjoy, R. 1988. Adunik Fal Baggan (Modern Fruit Science), 1st edn., Club Bhoban, BAU, Mymensingh, $45 \mathrm{p}$.

[9] Joy PP. 2010. Benefits and uses of pineapple. Pineapple Research Station (Kerala Agricultural University), Vazhakulam686 670, Muvattupuzha, Ernakulam District, Kerala, India (http://www.kau.edu/prsvkm/Html/BenefitsofPA.htm)

[10] http://nhb.gov.in/fruits/pineapple/pin012.pdf

[11] http://megapib.nic.in/pppineapple.htm

[12] Ubi W., Iqwe H., Ekpe S., Ibor O. 2005. Preliminary trial of fertilizer types on pineapple (Ananas comosus) grown on coastal and sands of Cross River State, Ni-geria. Global J. Pure and applied sci. 11(4):457-460. DOI: 10.4314/gjpas.v11i4.16534. 
[13] Rahim, M. A. 2012. Indiscriminate Use of Chemical in Fruits and Their Health Effects. Proceedings of First AFSSA Conference on 'Food Safety and Food Security' held at Osaka Prefecture University, OSAKA, Japan on September15-17, 2012. P 17-25.

[14] http://www.dhakatribune.com [Bangladesh: Chemical-free pineapple growers counting losses due to weak demand. Publication date: 9/8/2014].
[15] Hakim, M. A. and others, 2012. Role of Health Hazardous Ethephon in Nutritive Values of Selected Pineapple, Banana and Tomato. J. Food Agric. Environ.10 (2):247-251.

[16] Sogo-Temi, C. M., Idowu, O. A. and Idowu, E. 2014. Effect of Biological and Chemical Ripening Agents on the Nutritional and Metal Composition of Banana (Musa spp). J. Appl. Sci. Environ. Manage.18 (2):243-246.

[17] http://www.bbs.gov.bd/home.aspx. 